\title{
EDITCIRIAL
}

\section{Explosion in Anaesthesia}

A recent Judgment of the Supreme Court of Canada awarded damages against an anaesthetist for injuries suffered by a patient as a result of an explosion of ether vapour during an anaesthetio for tonsillectomy. This judgment suggests to us the wisdom of a critical examination of many of our current techniques to discover what elements of them might produce hazardous situations, which might be construed as negligence by the courts in case an accident should occur.

We doubt that the abandonment of explosive anaesthetic agents is desirable or practicable, although this has been advocatepd by some anaesthetists. Ether still remains the safest agent in the armamentarium of the occasional anaesthetist, and is probably the best agent in many crrcumstances in all hands. The usefulness of cyclopropane as a potent gas anaesthetic is widely established, and its use is unlikely to be discontinued in the foreseeable future The prevention of accidental explosions must, therefore, resolve itself into the problem of protecting the explosive mixtures from sources of ignition Dr Wishart's discussion of the explosion hazards in anaesthesia publishied in this issue is a timely reminder of the problem.

\section{Les Explosions et les SeRvices d’ANesthésIE}

Récemment la Cour Suprême du Canada a rendu jugement contre un anesthésiste, le condamnant à payer des dommages à un malade pour les blessures que celur-cı avait subies à la suite d'une explosion occasionnée par des vapeurs d'éther employées pour l'anesthésie au cours d'une amygdalectomı Un tel jugement nous incite à la prudence et 1 l nous suggère aussı de taue un examen sorgneux des technıques employées couramment pou dépıster où sont les éléments qu constituent un risque d'explosion, éléments qui pourraient être consıdérés comme une négligence par les cours quand suvient un accident

Nous doutons qu'il soit souhartable ou même possible de discontmuer l'usage des agents anesthésıques explosifs, bien que la chose alt été préconisée par certains anesthésıstes L'éther, dans l'armamentarıum de l'anesthésıste d'occasion, demeure encore l'agent le plus sûr et, dans bien des crrconstances, dans n'importe quelles manns, il demeure l'agent le plus sû.. L'utulité du cyclopropane comme gaz anesthésique ne fait aucun doute et, selon toute apparence, son usage ne semble pas devorr être abandonné dians un avenir prochain Il faut donc tenter de taire la prévention des explosions accidentelles en protégeant les mélanges explosifs contre les sources d'ignition L'article du Docteur Wishart sur les risques d'explosions en anesthésie, paraissant dans ce même numéro du journal, vient à point pour nous rappeler ce problème 